\title{
Modern Colonialism: Dialogues with Sefita Hao'uli, Kalafi Moala, and Melino Maka
}

\section{Abstract}

For this second article in a series of four stimulated by conversations about present day Tonga, Sefita Hao'uli, Kalafi Moala, and Melino Maka discuss whether there is a Tongan frame or explanation for development. And what about concepts and practices of self-determination? How can sovereignty and self-determination be realised as a national development plan when aid donors have such a tight grip over Tonga, they shape reality in the present and prospects for the future? Linking the discussants' ideas with the work of the late Tongan professors Futa Helu and Epeli Hau'ofa, Teena Brown Pulu examines why Tongans in the homeland state are socialised by a zealous nationalism that does not question, whose development history is this?

\section{Prelude to the Text}

The problem with modern colonialism, as I see it, is not so much with the colonial powers themselves but rather with those colonized states that put themselves at the mercy of those who make decisions to determine their future. (Moala, 2013a).

Teena Brown Pulu has a PhD in anthropology from the University of Waikato. She is a senior lecturer in Pacific development at AUT University. Her first book was published in 2011, Shoot the Messenger: The report on the Nuku'alofa reconstruction project and why the Government of Tonga dumped it. 


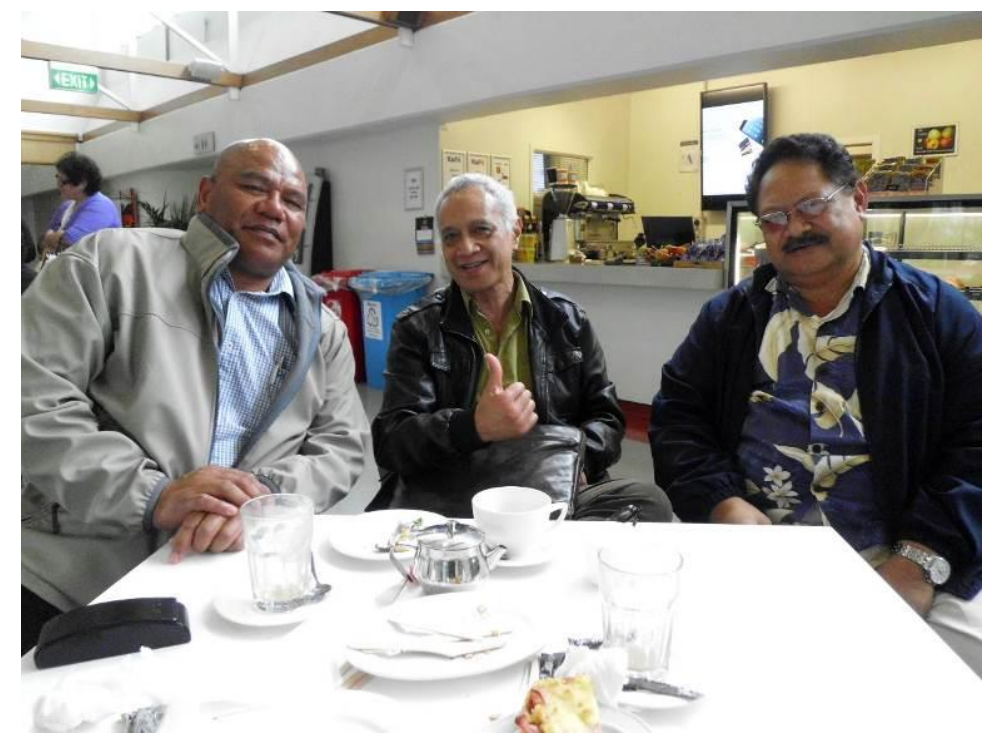

Left to right: Melino Maka, Sefita Hao'uli, and Kalafi Moala in development conversation over morning tea at AUT University Manukau campus on Tuesday 13 November 2013.

Go for broke was Kalafi Moala's attitude. A colloquialism traced to Hawaiian Pidgin English during World War II, he wagered everything he had by pulling no punches in his political commentary. It was published online by the Pacific Institute of Public Policy based in Port Vila, Vanuatu. With purposeful and provocative words courting trouble with his homeland state, the Government of Tonga, Moala was no novice at authoring controversial opinion pieces. Framing the analysis in respect of Tonga, "the problem with modern colonialism" is that church, state, and society have been systematically indoctrinated to resist, repel, and reject the idea that colonialism is pivotal to understanding the country's past, present, and future development (Moala, 2013a).

Tonga was never formerly colonised is the chorus call sung from hymn books, history text books, and political rule books 
where independence, sovereignty, and freedom echoed in the 1875 constitution have become romanticised ideals reverberating loudly in the national motto, God and Tonga are my inheritance. What is modern colonialism in Tonga's present democratic arrangement, or economic colonialism as the alternative term? And how does it form trajectories for reading the past and determining the future in relation to development?

This second essay of four stirred by development dialogues with Sefita Hao'uli, Kalafi Moala, and Melino Maka questions the relationship between economic colonialism and state sovereignty in present day Tonga. Is it possible to manufacture democracy in a small island developing state without economic security? Subsequent to this, how have the conflicting approaches of regional interdependence and subregional independence affected Tonga's geopolitical direction in forging closer bilateral ties to China? With the New Zealand and Australian dominated Pacific Islands Forum under criticism to be more relevant to the development priorities of Pacific Island states, and with the Melanesian Spearhead Group under Fiji's influence to strengthen the sub-regional alliance to counter New Zealand and Australia's control over South Pacific countries, how has Tonga manoeuvred and repositioned itself?

It was the late Tongan professor, Epeli Hau'ofa, who first wrote of a "substantial regional identity" rooted in "the Pacific Ocean" (Hau'ofa, 1998, p. 392). Fifteen years ago in The Contemporary Pacific he named his classic piece The Ocean in Us (Hau'ofa, 1998), noting that modern history was marked by failed efforts at coordinating Our Sea of Islands (Hau'ofa, 1993) into a regional organisation of Pacific Islands polity which performed with relevance and meaning to the diverse peoples of Oceania. This, he felt, was exacerbated by the fact that "we have lost sight of the ocean that surrounds and sustains us" (Hau'ofa, 2000, p. 33). 
I wish now to take this issue further by suggesting the development of a substantial regional identity that is anchored in our common inheritance of a very considerable proportion of the Earth's largest body of water, the Pacific Ocean. ...We have not been successful in our attempts so far because, while fishing for the elusive school of tuna, we have lost sight of the ocean that surrounds and sustains us. (Hau'ofa, 2000, pp. 3233).

Hau'ofa stressed that constructing a homogeneous Pacific Islands identity for conducting regional cooperation was not going to work. Instead he proposed that "collective interests" based on safeguarding "the ocean" for both territorial sovereignty and environmental sustainability be the "common identity." In this sense, ocean origins and independence from the majority of the world's wealth "that encircle us" in Pacific Rim countries was the social glue binding Pacific Island states regionally (Hau'ofa, 2000, p. 33).

A common identity that would help us act together for the advancement of our collective interests, including the protection of the ocean for the general good, is necessary for the quality of our survival in the so-called Pacific century when important developments in the global economy will be concentrated in huge regions that encircle us. ...I am not in any way suggesting cultural homogeneity for our region. Such a thing is neither possible nor desirable. (Hau'ofa, 2000, p. 33). 


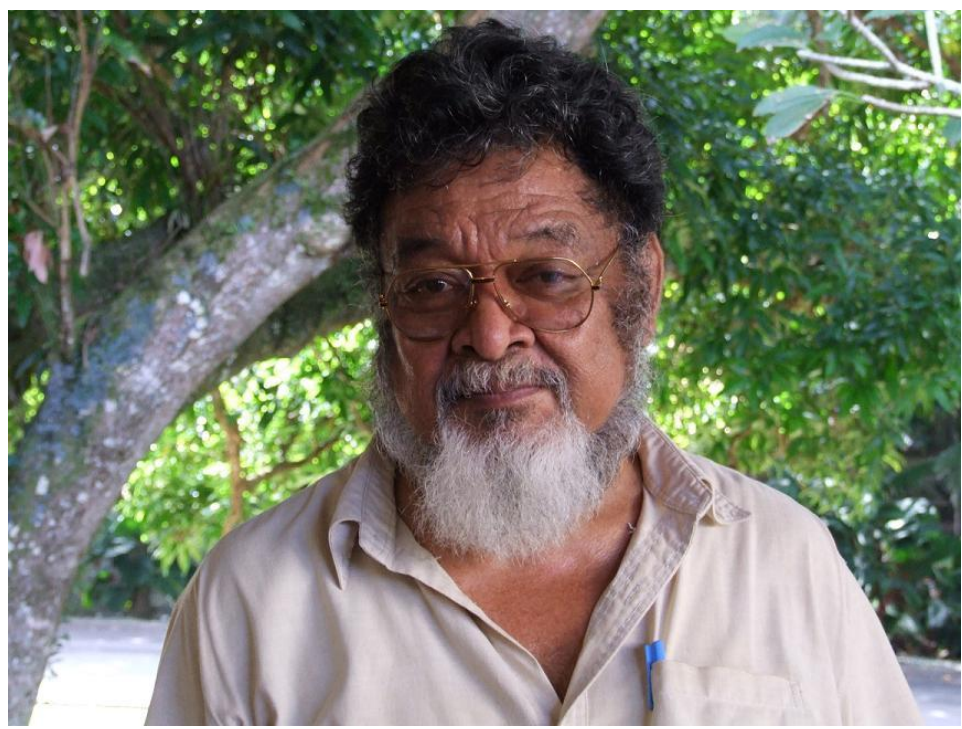

The late Epeli Hau'ofa who was a Tongan professor of sociology and director of the Oceania Centre for Arts and Culture at the University of the South Pacific in Suva, Fiji. (Photograph by Ann Tarte).

Hau'ofa's notion that an expansive ocean is a unifying force, an ancient travel and trade route, an inherited identity for Oceanic peoples and Our Sea of Islands, which was a reference point he first coined in 1993, has become politicised symbolism in the 21 st century. The establishment of the Fijiled Pacific Islands Development Forum, an orchestrated response to the conventional Australian and New Zealand-led Pacific Islands Forum, brands its regional polity as unity by a shared ocean. At high-level talks between Pacific Island bureaucracies, the ocean now represents the mutual heritage of Pacific peoples and their most valued natural resource escalated, of course, by an elusive promise that there is economic profit to be made in state-sponsored deep sea mineral exploitation conducted by multinational companies from developed countries. 
However, the long-running tension between regional and national interests still persist, expressly for this essay through the Tongan state mentality that believes our islands "are too small," resource poor, and "too isolated" to live beyond economic "dependence" on aid donors (Hau'ofa, 2008, p. 29). Hau'ofa makes this point crystal clear, mapping the power of this origin myth to "social scientists," the knowledge brokers of a global economy dominated by developed country universities and research and policy institutes (Hau'ofa, 2008, p. 29).

It is a belittling view that has been propagated unwittingly mostly by social scientists who have sincere concern for the welfare of Pacific peoples. According to this view, the small island states and territories of the Pacific, that is, all of Polynesia and Micronesia, are too small, too poorly endowed with resources, and too isolated from the centres of economic growth for their inhabitants ever to be able to rise above their present condition of dependence on the largesse of wealthy nations. (Hau'ofa, 2008, p. 29).

Remembering that Hau'ofa's 20th century paper, Our Sea of Islands, is twenty years old, there is little in the human psyche he recounts here that has shifted in the 21 st century Tongan state and society, a South Pacific country which has been democratised since the general election of 2010. His words evoke commonplace imagery of Pacific Island states that have become, in the present day, a heightened reality; specifically the proliferation of "MIRAB societies," which are small island developing states perpetuating economic dependence "on migration, remittances, aid, and bureaucracy" (Bertram, 2006; Massey and Taylor, 2004).

Our national leaders were in the vanguard of a rush to secure financial aid from every quarter; our economies were stagnating or declining; our environments were deteriorating or threatened and we could do little about it; our own people were 
evacuating themselves to greener pastures elsewhere. Whatever remained of our resources, including our exclusive economic zones, were being hawked for the highest bid. Some of our islands had become, in the words of one social scientist, "MIRAB societies" - pitiful microstates condemned forever to depend on migration, remittances, aid, and bureaucracy, not on any real economic productivity. (Hau'ofa, 2008, p. 29).

Drawing on ideas from Hau'ofa's work in the 1990s, this paper unravels the impressions of Sefita Hao'uli, Kalafi Moala, and Melino Maka in conversation about Tonga's current economic predicament, a condition that exhibits two-fold tensions. First, how has weak financial sovereignty and increased aid dependency impacted on this fledgling South Pacific democracy and the geopolitical shift toward China? Consequently, what is the emerging pattern of Pacific Islands' development in the 21 century, and is there a Tongan way of conceptualising and doing development that prioritises selfdetermination as the benchmark of national identity?

Sovereignty in Tonga's modern history is a euphemism for freedom, the type of independence signified in the political organisation of a sovereign nation, as well as civil liberties guaranteed to Tongan citizens in the 1875 constitution such as rights to religious expression, association, speech, press, and suffrage. The contradiction, however, in Tonga's contemporary setting as a post-2010 democratised state, is that it is unclear how the 19th century ideology of a constitutional monarchy translates functionally into a 21 st century parliamentary democracy.

Complicated by regional economic integration, the reality is that development represents an imported catchphrase and value system loosely wielded around by politicians and state bureaucrats to mean anything and everything to every Tom, Dick, and Harry. Development is not defined or owned by Tongans, themselves. The public service and parliamentary discourse on development, in actuality, boils down to nothing 
Tongan by historical origin, nor exclusively Tongan in social orientation. It is, in fact, behaviour that is learned, borrowed, and copied largely from the West (Said, 1978).

We imitate development like The Signifying Monkey (Gates, 1988), a text on African American literary criticism by Henry Louis Gates Jr. ${ }^{1}$ (Hammond, 2005; Kochman, 1972). By this, I mean that references to development have become part-andparcel of everyday Tongan vernacular broadcasted by the state as a brainwashing exercise that also dissuades the masses on its receiving end from questioning where, historically, have these formal traditions come from? Whose development history is this? The truth is, inside the island Kingdom no one ever asks. Therefore, this essay makes a straightforward inquiry: What is Tongan national identity under a newly contrived democratic arrangement, and how does it reflect or deflect Tongan-defined principles of development as selfdetermination?

\section{Discourse on development}

The challenge of my project, if not exactly to invent a black theory, was to locate and identify how the "black tradition" had theorized about itself. (Gates, 1988, p. iv).

All human-made tradition, to a certain degree, is invented, reinvented, and involves mimicry of the past modified for the political conditions of the present (Hobsbawm and Ranger, 1983). None so much as "invented tradition," which gives off the aura of having deep-roots in culture that have stood the lengths of time when in actual fact, it is a system of customs and formalities concocted quite recently. Eric Hobsbawm and Terence Ranger's classic text, The Invention of Tradition first published in 1983, is an essay collection unfolding how and why tradition is invented as a method of social control by way of manufacturing rituals and symbols of national identity. 
In Hobsbawm's account, he made known that "the pageantry which surrounds British monarchy in its public ceremonial manifestations ... in its modern form it is the product of the late nineteenth and twentieth centuries" (Hobsbawm, 1983, p. 1). It was not, as the British public of commoner class had generally imagined, a product of ancient and unbroken tradition. Hobsbawm argues that "invented tradition" by its "symbolic nature," sentimentality, and replication in society indoctrinates people to behave in certain ways and adopt specific values which they uncritically believe have a long history in their country and nation-wide culture.

'Invented tradition' is taken to mean a set of practices, normally governed by overtly or tacitly accepted rules and of a ritual or symbolic nature, which seek to inculcate certain values and norms of behaviour by repetition, which automatically implies continuity with the past. (Hobsbawm, 1983, p. 1).

For non-Western cultures and languages, inventing tradition in today's globalised world usually amounts to integrating Western thought and practice with localised knowledge and know-how. Illuminating this point, Tongan artist Walter Holakeituai spoke to Television Tonga News about one of his art pieces that won a local competition sponsored by the government office of the speaker of the legislative assembly. It was Holakeituai's prediction about the future that explained innovation through modifying tradition is necessary for sustaining culture. In his view, Tonga will become increasingly Westernised. "It is much easier," he thought, to invent new traditions relevant to contemporary living environments, rather than hold on to past ones in their original form when the past, by no means, mirrors how the present truly is (Holakeituai in Television Tonga News, 2013b).

I used weaving for my art. It is one of our traditional and cultural tasks. I chose it so it would show how time has gone 
by and the Western ways are mixed with our own traditional Tongan ways. How I see the future is that more things will be done in the Western style as it is much more easier. (Walter Holakeituai cited in Television Tonga News, 2013b).

The visual artist's interpretation of where Tonga is headed is a style of thought borrowed from the arts and literature community. I could argue the most truthful narratives about Tonga's past, present, and future - which was the theme of the local art competition Holakeituai won - may not necessarily emerge from social sciences, the research territory I inhabit and practice that dominates the Pacific Islands development industry. Instead, an independent interpretation of development in a Third World state is created by artists, performers, and fictional writers. Why would the humanities expressly arts and literature - give a more authentic and closer-to-the-bone account of what is really going on in everyday Tongan life, the true development tales and trajectories of the people without power, the ordinary folk?

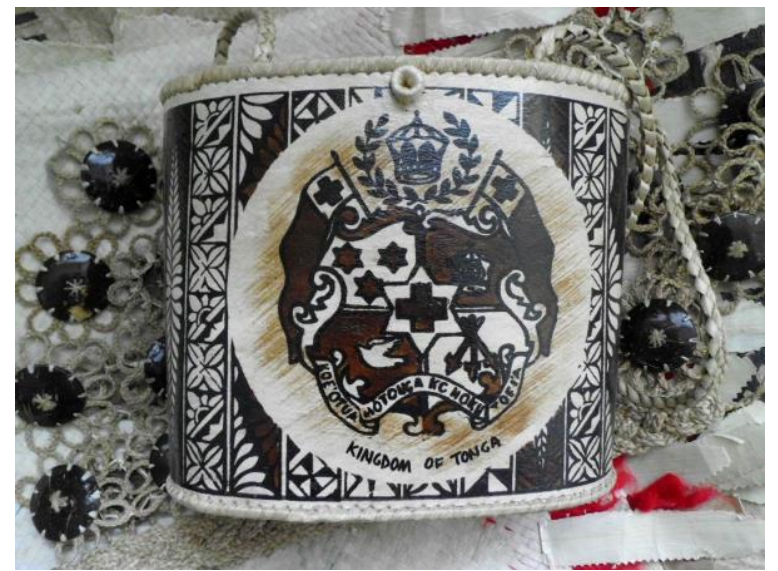

Small handcrafts such as this handbag made from bark and fibre and painted in natural dye are popular items purchased by tourists, including Tongan ex- 


\section{patriates living overseas, from women's crafts collectives and market stalls in Tonga.}

First and foremost, an artist's freedom of interpretive expression is a fiercely guarded principle of practice. Mutually related to this, social scientists are too readily bought-off by the development industry to regurgitate state narratives. What I am saying is similar to consultants riding the aidgravy-train, social scientists are often remunerated by governments looking to contract a pricey set of research findings tabulated in an official report, which the state can disseminate to the public to fulfil its own political will.

Here, I am alluding to Gramsci's notion of hegemony in which the government rules over and dominates formal proceedings circuitously, obliquely, and indirectly (Gramsci, 1971; Freire, 1970). In this relationship context, there is a subtle coercive influence at work. An implicit expectancy of the government contractor towards the contracted researcher is that payment is conditional to terms of agreement, which in so many words, tell the contractor what results the state anticipates to be assembled on paper.

As Michel Foucault suggested, there is a peculiar, particular, and pervasive discourse of development which the Western world has manufactured and exported to the nonWest, the Third World, the poor, pitiable, impoverished developing nations of coloured Natives and non-European cultures and languages. Discourse by Foucault's (1972) analysis in The Archaeology of Knowledge are the inherent power relations operating between social groups.

Expressly, discourse is embedded in language which brings into being, consciously and reflexively, speech and behaviours representative of how a society governs, controls, regulates, and disciplines people into being subjects of power and authority (Foucault, 1972, 1983). Foucault first introduced discourse in an inaugural lecture at the College de France in 1970 where he presented a discourse hypothesis 
that explored the mechanisms of social control policing and regulating the transmission of speech and ideas.

...in every society the production of discourse is at once controlled, selected, organised, and redistributed by a certain number of procedures whose role is to ward off its powers and dangers, to gain mastery over its chance events, to evade its ponderous, formidable materiality - in a society like ours, the procedures of exclusion are well known. The most obvious and familiar is prohibition. We know quite well that we do not have the right to say everything, that we cannot speak of just anything in any circumstances whatever, and that not everyone has the right to speak of anything whatever. (Foucault, 1970, p. 52).

The discourse on development therefore sets out to perform two correlated tasks which dominate the subject by the use of power and coercion. As Foucault writes, the very concept of development associated with "evolution," growth, and progress allows a person in a position of power to connect and compare random and unrelated "events," statistics, data, information, and occurrences in a straight line of history (Foucault, 1972, p. 22). The storyline fashions a version of history, a record, an account, a report on development, which the receiving audience is instructed to unthinkingly consume as fact, truth, and accuracy.

Mutually related to the first point is the fact that the "origin" moment, the birthplace and founding sources constituting the development history being related to an audience, "are never given" willingly by the narrator but remain veiled and concealed in the story's plot (Foucault, 1972, pp. 22-23). Effectively, this permits the "origin" of the development term itself to escape being defined and described in the context of which the narrator has shifted and sculpted its root meaning to force their political will, their conception of development. In saying this, development is an elusive 
reference to an accepted wisdom that goes largely unchallenged and unopposed because it transmits a universal impression of advancement and improvement. But in the end, it is a highly contextualised instrument of power manoeuvred by those who dominate the discourse on development to make others the silent subject of their "notions," ideas, and beliefs (Foucault, 1972, p. 22).

There are the notions of development and evolution: they make it possible to group a succession of dispersed events, to link them to one and the same organising principle, to subject them to the exemplary power of life (with its adaptations, its capacity for innovation, the incessant correlation of its different elements, its systems of assimilation and exchange), to discover, already at work in each beginning, a principle of coherence and the outline of a future unity, to master time through a perpetually reversible relation between an origin and a term that that are never given, but are always at work. (Foucault, 1972, p. 22-23).

What is the Tongan explanation of development? In Tongan state law, policy and regulations, how have references to and inferences about development been specifically designed to represent a wide-ranging consensus of citizen opinion in respect to their living conditions and environments? What drives the logic and method of practice that Tongan state bureaucrats use to formulate the Kingdom of Tonga's discourse on development? "In short, you will never know," said Jacques Derrida (1999).

\section{National pride and prejudice ${ }^{2}$}

"This is internal colonisation." Over morning tea with Sefita Hao'uli, Kalafi Moala, and Melino Maka at Auckland University of Technology's Manukau campus, I could feel my voice switching up in volume. "That doesn't matter," retorted Sefita 
wearing an expression that read, so what? "But we colonised ourselves. Tongans colonised ourselves with the British monarchy and nobility system that sacked the chiefs." My glorious comeback. Exerting emphasis and effort into spitting my point across the café table, as a child of migrants, a New Zealand citizen with British and Native half-cast roots planted in the Kingdom of Tonga, I figured I was one-up on the fullblooded Tongans studying my performance. Sefita and Kalafi's faces told me their minds had not budged. The score was still two to one to the so what side.

Melino Maka was drinking his coffee and sitting on the side line. He was meant to be on my team to even out the sides, two on two, me and Melino versus Sefita and Kalafi. But I was barking up the wrong tree. It was a redundant argument I was picking with Sefita Hao'uli and Kalafi Moala during our development dialogues that sometimes transformed into debate, depending on who had a bone to pick. After 138 years, the monarchy and nobility were a permanent fixture. The people could not shaft them. If they went there, the land tenure system would come undone and Tongans would get done over by property privatisation and the sale of land to foreigners.

This is what we got from a 19th century constitution: The creation of a Tongan King who took up Protestant Christianity plus a Westminster model of parliament putting the nobles and the commoners in the same House. Sharing the same House more often than not set off relationship chaos. But there was always the hallucinatory influence of being proselytised by the national motto; God and Tonga are my inheritance. Amen and $\mathrm{A}[\mathrm{wo}] \mathrm{men}$, seeing the rights of women and children had descended upon 21 st century Tonga, and not without the odd noble in the legislature voting against the right for women to be protected against domestic violence under the law. 


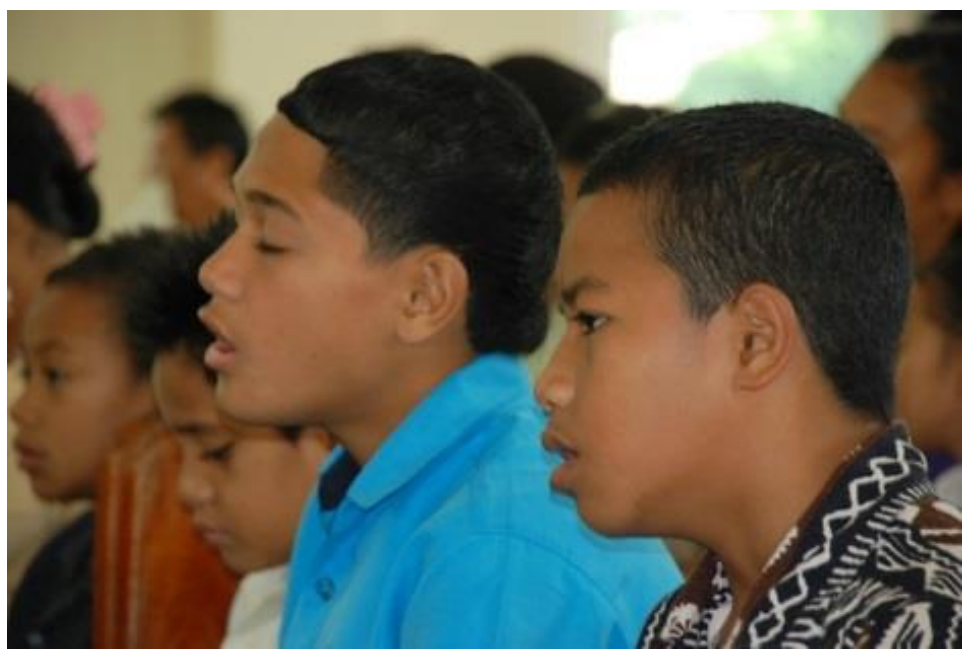

Tongan boys seated up the front with the children of the congregation singing hymns at the Wesleyan Church in Nukunuku, Tonga.

Symptomatic of the dual obsession with tradition and modernity, the Tongan state had choreographed a national development dance of shuffling in an uncoordinated fashion forward, backward, and side-to-side, but always in hierarchal formation to discipline the ordinary folk into not stepping out of line. The result of keeping like this was predictable: Tonga was a small island developing state going nowhere fast. However, government-owned media reported Tonga was thrilled to pieces with its development.

I have never been able to pinpoint where the collective xenophobia of Tongans born and raised in the homeland state originated. To be ruthlessly brusque, it offends my born and raised in New Zealand sense and sensibility. ${ }^{3}$ An alarming public exhibition of racism is to see, hear, and watch Tongans display arrogance, ignorance, and wilful prejudice toward others who are not Tongan by blood relationship. Intuitively, I have always suspected Tonga's public education system compounded by church organisations are contributing 
institutions which programme young minds, young people, to grow into adults grossly misled about their self-importance as if they are some kind of superior breed, ancestry, and gene pool.

Futa Helu, the late Tongan professor, critiqued Tongan jingoism in fierce and frightening detail. Fierce, because he states a cultural truth founded on lived experience. Frightening, because based on research activity in Tonga and dealings with Tongans in Auckland where I work and live, including my biological relatives, his value judgement makes sense to me. What I am saying is there are strands of nationalism - The Good, the Bad and the Ugly (Leone, 1966) ${ }^{4}-$ transferred across generations and geographical distance from the origin homeland to its outposts, to Tongans overseas that is. For what purpose is patriotism packaged and reproduced? How does a nation, which in the present is both homebound and transnational, change the branding label to reflect a modified market of identity consumers that have moved away from debilitating behaviours which predominated in the 19th and 20th centuries?

Take tolerance, for example, I cannot name one Tongan (except Kalafi, perhaps) who has had any meaningful experience of the sentiment. The upshot of this is every Tongan, but especially members of the upper classes, have prodigiously overblown egos, and are massively deluded as to their worth as persons, the pre-eminence of their families and the impossibility of maligning them or their own in any way. (Helu cited in Moala, 2002, p. 8).

Futa Helu could say this, publish it, mean every word, and get away with it in Tonga. He was a man not a woman, and revered across the class spectrum for fearlessly validating his opinions in the public domain. For myself, I am not sure if I will live to write an uncensored tale in my academic lifetime. Every piece I author is toned down, tamed, and trimmed. By 
even speaking of full-blooded affairs in my tenuous position as a woman, as a Tongan-hybrid, involves taking considerable risk. The plain truth is the political and social institutions which Tongan nationalism is structured under, namely the state and the church, might react against me and could, if certain authority figures feel whimsically provoked and poked, attempt to shut me down, shut my mind, shut it off. For that is the Real Tonga, ${ }^{5}$ the not so friendly islands that I know so well in a coconut shell.

Rewind to the development conversation with the three discussants on Tuesday morning of November the 12th, 2013. It was Sefita Hao'uli who gave me some of the missing texts and explanatory notes for my library of development knowledge. Kalafi Moala willingly joined his childhood and adolescent memoirs with Sefita's, shining more light on how Tongans are socialised at school towards nationalistic pride, pomposity, and pageantry.

"When we were at school, one of the most popular hymns or songs if you like sung by students was about Tonga being the centre of the Pacific. It made disparaging remarks about other countries. That song is still sung today." Putting his thoughts into plain words for my benefit, Sefita had a key message: Tongan nationalism was indeed learned behaviour acquired during childhood socialisation. Listening to the recollection and taking down his talk verbatim in my notebook, I had to ask, "Where can I hear this song?" "It's still sung today. It's still popular today," he repeated. 


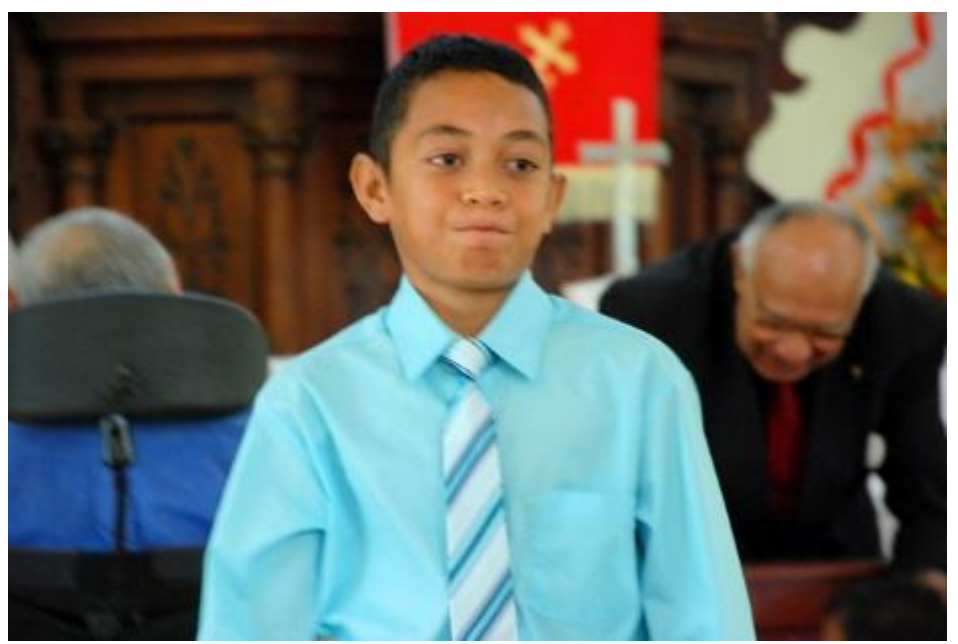

A Tongan boy returning to his seat after receiving a blessing from the Minister at the Wesleyan Church in Nukunuku, Tonga.

Caught in a confused moment of disbelief, I wanted to rest my head in my hands to stop the dread from rising in my chest. Surely middle-aged parents of my generation who had received a liberal university education whether in the Pacific Rim countries of New Zealand, Australia, and the United States, or at the University of the South Pacific in Suva, Fiji, would object to their primary and secondary school children singing a quasi-anthem that encouraged extreme nationalism.

Kalafi put the singing in context. "There are disparaging remarks in the song. The 'poor Indians,' which is like saying they're to be pitied because they're not Tongans. We were taught at school we're the children of the Pacific, the centre of the Pacific."

"Didn't you question what you were singing? The racial undertones, 'poor Indians,' did you think about that?" My voice conveyed that in my mind, this was abysmal, appalling behaviour. "No," Kalafi said flatly. "That was the normal school environment. You just sang along. There was a great 
feeling of pride." "It's still sung today in Tonga," added Sefita a third time. His will to impress on me the deep-seated tradition embedded in the Tongan public education system resounded loud and clear. Indoctrinating children and young people through nationalist songs that reared racial intolerance, a dislike of foreigners, and outright prejudice, was, as Kalafi put it, "the normal school environment." (Anderson, 1983).

In a perverse way, pitying Indians of dark skin and poor country status gave Tongans a sense of national pride. It made them feel better about themselves in having a superior class of dark skin and poor country status among the Third World poorhouse created by the wealthy countries of the developed West. This psychological state of thinking that dark skin equates to poverty and racial inferiority did not sit right with me. I found it abhorrent. I had not been subjected to schooling in Tonga. For that, I felt immeasurable gratitude to my parents and migration (Massey and Taylor, 2004).

Looking at Sefita Hao'uli and Kalafi Moala's school experiences of singing 'poor Indians' in a quasi-anthem flaunting Tongan nationalism, parading its Christian religiousness as superior to the dark skin heathens of nonWestern culture and poor developing country status, why poor Indians? Why not poor British, poor French, poor Germans, poor Americans, poor white New Zealanders and Australians the European empires and its overseas diaspora (the USA, New Zealand, and Australia) to have colonised the South Pacific?

Why not feel pity and shame on Western Europe and its settler colony outposts, the actual perpetrators, offenders, and wrongdoers in history? White is not colourless, cultureless, impartial, and neutral. White is a highly politicised reference for power, domination, and supremacy over darker colours. Get real Tonga, and I am not alluding to the domestic air service for the outer islands by the same name, Real Tonga. 


\section{Historiography of the local colonial state}

Arriving home from work that November Tuesday evening, I mulled over internal colonisation carried out by national identity projects. By what modes and means does a small island developing state like Tonga, annex, occupy, and dominate the thought-processing and rationalisation capabilities of its people, incapacitating them from thinking and operating beyond the structural constraints fortressing the national identity matrix of monarchy, hierarchy, patriarchy, class, race, church, and state? Looking for answers as to how this perplexing phenomenon gains a stranglehold over a country, its stifling ideology duplicating itself throughout two centuries from the 19th to the 21st, I turned to Robert Young's text, White Mythologies: Writing History and the West (1990).

But how to write a new history? When, as Cesaire observed, the only history is white? The critique of structures of colonialism might seem a marginal activity in relation to the mainstream political issues of literary and cultural theory, catering only for minorities or for those with a specialist interest in colonial history. But although it is concerned with the geographical peripheries of metropolitan European culture, its long-term strategy is to effect a radical restructuring of European thought and, particularly historiography. (Young, 1990, p. 119).

Historiography, taken to mean written and oral texts, are reworked into subtexts and counter texts with the purpose of delivering and disseminating alternative narratives to "European thought" (Young, 1990, p. 119). This is particularly the work of The Post-Colonial Critic (1990), as Gayatri Spivak's book attested to. Postcolonial, in this sense, is not intended to mean after colonialism but rather, the term itself signals that spectres of colonial thought, speech, and behaviour persist in the present and will continue into the future because, to 
borrow Futa Helu's words, "in life, we always want to achieve some degree of permanence, a tradition" (Janman, 2012).

In saying this, what was Tonga's 19th century endeavour to rearrange "European culture" and "European thought?" (Young, 1990, p. 119). By transfiguring its cultural system of organisation into a constitutional monarchy, how did this contest the pervasiveness of a Eurocentric world?

In a nutshell, Tongan mimicry of the British monarchy and empire was the political tactic for warding off colonial annexation of the islands. By centring its own monarch not the British one as the head of state and the head of the Free Wesleyan Church, the first King of Tonga George Tupou I became the fundamental symbol for Tonga's modern statehood. The Kingship personified permanence, stability, and constancy, as well as giving the impression that the Kingdom of Tonga had an ancient monarchical past. Of course it did not, with Sione Latukefu being the first Tongan historian to publish in his 1974 book, Church and State in Tonga, that a definite rupture had occurred (Latukeu, 1974). By this, Latukefu saw a deliberate breaking with a traditional past was enacted in 1875 when the constitutional monarchy of the Tupou family entered into power.

And this is where the penny dropped for me. I could see Tonga's 19th century internal colonisation with the advent of the Tupou monarchy and the adoption of Christianity as the state religion sought "permanence, a tradition," to paraphrase Futa Helu (Janman, 2012). The lingering fear was that dismantling the entire gamut of the monarch's political power, now that Tonga was a parliamentary democracy, would unhinge the "local colonial state" and institutional structure (Anderson, 2006, p. xiii). To unravel the social fabric would destabilise the very foundation which bound the monarchy and the nobility to their estates and the commoners, the state to its citizens, and the church to the country's national identity. 
But there was still the reoccurring problem of power being executed by top-down brute force in Tonga. It made change from below, pushing against the status quo, painfully slow. If the truth be told, the people at the bottom buttressing its weight were feeling suppressed, becoming restless, agitated, and frustrated with a repressive regime of state authority that replicated class structure (Moala, 2009). Even the commoners imitated the ruling elite and reinvented class structure in their churches, workplaces, communities, and family settings. Therefore, it was well known among the masses that Tongan bureaucrats and politicians shared a common aspiration: Together, they showed little conscious effort to modify the state's organisational behaviour since democracy's arrival in 2010. Why would they reform? Public servants constituted the state and had it good, got government perks, compared to the ordinary masses outside the bureaucracy.

In 2009, Kalafi Moala authored his second book called, Tonga: In Search of the Friendly Islands. Narrating how and why the Nuku'alofa riot of November 16th 2006 exploded into history, shaking the conservative foundation of modern Tonga, he had a sharpened point to get across to readers. There was a concise explanation for the uniqueness of Tonga's political history. For two centuries of the modern era, the commoner people felt that it was their own Tongan ruling class who were the most oppressive power over their lives; a far greater force of tyranny, repression, and cruelty, than European foreigners. Here, Moala gave a lead as to why Tongans were impressionable, trusting, and uncritical toward white people in their country, while on the other hand, they viewed the monarchy and nobility with suspicion, distrust, and disbelief.

Irking Moala and driving his analysis is the fact that systematic oppression allows the rulers to patronisingly assume they know best for the poor, wretched fools whom they rule over. A paternalistic relationship therefore reduced adult commoners to the status of children, wards of the state, whose decision-making power was deliberately taken from them, and 
who are only officially dealt with when they are disobedient and in need of punishment.

One of the most oppressive assumptions made by the ruling elite is that the commoner people are not only "stupid" and "barbaric" but they also do not know what is good for them. So, the ruling elite must decide what is good for the people. Someone from outside the "box" must determine what is good for those "inside the box." Sin is viewed as having nothing to do with violation of basic and universal laws and principles, but rather "not fitting" into one's place, or being culturally a social misfit. It is interesting that this is the attitude that all tyrants have possessed throughout the ages, from Stalin and Hitler to Saddam and Suharto. These tyrants set out to put the oppressed "in their place." (Moala, 2009, p. 126).

Moala published his book, Tonga: In Search of the Friendly Islands, almost 2 years before the 2010 generation election ushered in democratic reform for the Tongan state. In 2013, however, change management in Tonga's public service has not eventuated the way that management textbooks proposed (Anderson and Ackerman Anderson, 2010); that is, by transforming state departments and ministries to work productively in a modern business environment. Contrarily, the state goal turned out to be preserving the status quo, as well as job security, by minimally going about business-asusual. This marked the bureaucracy's way of laying its roots to achieve perpetuity in a new system that took on the external trappings of a democratic arrangement. In reality, the new bureaucracy entrenched old lop-sided power relations along with the public service mentality of kai suka, literally meaning that public servants eat sugar by relishing in a privileged, indulged, spoilt lifestyle.

Benedict Anderson's book, Imagined Communities: Reflections on the Origin and Spread of Nationalism, was first published in 1983 and reprinted in 2006. In many ways, the 
first comprehensive text to map out why nationalism is a global phenomenon, and how "imagined communities" based on one's nationality are created and maintained in the homeland state and in diaspora, there was one area Anderson noted requiring deeper investigation. It is, importantly, a subject of study relevant to understanding Tonga's national identity troubles in transitioning from a Kingdom with an absolute ruler to a Kingdom where both a participatory democracy and a monarch with political power are at work, mostly in conflict.

A number of friendly critics had suggested that [I] oversimplified the process whereby early 'Third World' nationalisms were modelled. Furthermore [I] did not seriously address the question of the role of the local colonial state, rather than the metropole, in styling these nationalisms. I became uneasily aware that what I had believed to be a significantly new contribution to thinking about nationalism - changing apprehensions of the time - patently lacked its necessary coordinate: changing apprehensions of space. (Anderson, 2006, pp. xiii-xiv).

Anderson's emphasis on "the role of the local colonial state" in shaping nationalism, and how nationalism triggers "changing apprehensions of space," relates to Tonga's current quandary. The "local colonial state" has, by no means, gone away (Anderson, 2006, pp. xiii-xiv). It persists with a constitutional monarchy and landed gentry, the traditional land owning class. But what has come into play is not singly the democracy riddle in terms of negotiating this political arrangement alongside a monarchical hierarchy that still retains political power. Added to the mix are competing aid donors rivalling for spheres of influence - economic and diplomatic space - in South Pacific countries and the subregion. 
Put simply, it is Tonga's shift towards China as its main bilateral development partner, while the Deputy Prime Minister Samiu Vaipulu obstinately avowed to local media that relationships with New Zealand and Australia are not strained but steady which expose, if anything, political camouflage. "Apprehensions of space," as Anderson put it (Anderson, 2006, p. xiv), are internalised by ordinary citizens and expressed through high levels of anxiety over Chinese soft loans, a waning economy, and fear that China might demand tuna fishing licences, increased immigration quotas and business licenses, as well as land leases, in return for cheque book diplomacy.

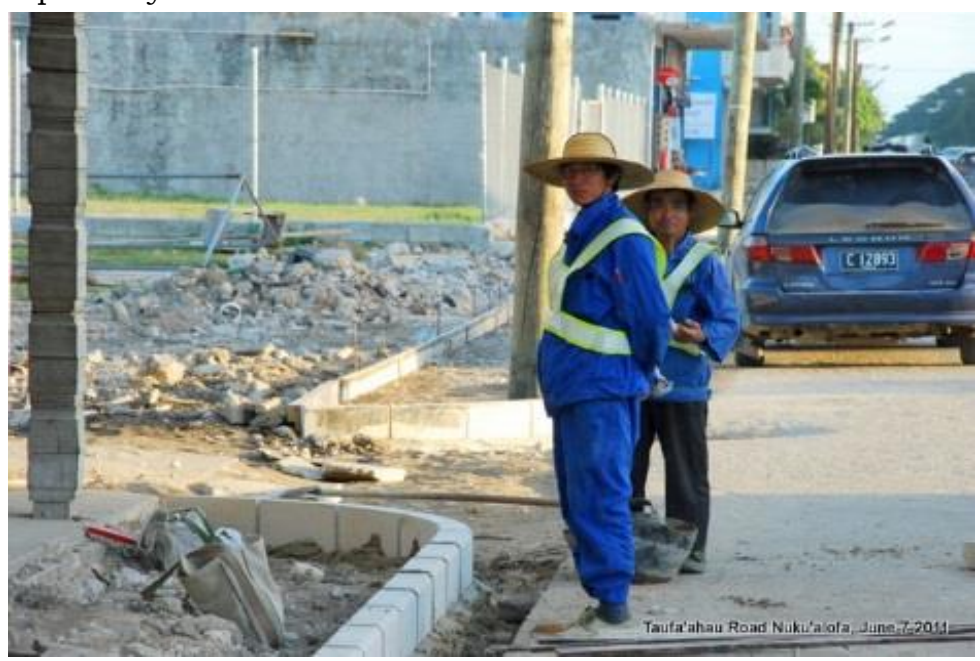

Chinese employees of Chinese Civil Engineering Construction Corporation working on the Taufa'ahau Road pavements paid for by an EXIM Bank of China loan, Nuku'alofa, Tonga.

In Tonga, cheque book diplomacy is the basis of foreign relations, not romantic notions of neighbourliness towards Fiji and Samoa whose South Pacific histories are woven into Tonga's through a pre-colonial past of intermarriage, warfare, and trade. Tonga's style of having a cosy affair with China, 
and relationships on the side with New Zealand, Australia, and the USA, does not happen without an economic cost to the country. Tuna fishing licenses and oil and deep sea mineral exploration licenses granted to overseas companies at bargain prices are tell-tale signs that aid equals trade, or more fittingly, a trade-off. In other words, nothing is given for nothing in return. The question is how will Tonga's foreign affairs model pan out over the next decade? Furthermore, in relation to sustainable business, what will this mode of operation cost the younger generation's future in terms of trading limited natural resources for aid, grants, and soft loans?

\section{A short play: Scene one: The parable of sharing}

Sefita Hao'uli: You might be short 10 dollars or 10 million dollars but the point is that there is a need. Development is the market for buying and selling, and it shouldn't be. If we change the thinking to a sharing lens where we look at development as a sharing proposition on the basis of reciprocity - not a mentality of helping, a hand-up, or a hand-out - then that reframes the buying and selling relationship, where the relationship has always been based on one being the stronger, dominant, domineering partner. What we should be doing is revising donor dynamics by putting forward a 5 year plan where donors are invited to come, sit at the table, and talk to one another on the basis of sharing to implement the country's 5 year development plan. The situation is that the poor are in need and have little to give back. Therefore, the rich with excess wealth are to give their surplus away, not trade it away to the poor. Buying and selling aid for trade is bullying. The ethical approach is that if the donor is willing to share by fair, ethical, equitable, and defensible principles then they are seated at the table to discuss the 5 year plan and sharing what resources the donor can contribute. (Hao'uli, 2013b). 
Melino Maka: The development model that Tonga has, is the donors. It's not the recipient country that tells the donor what development is, and that's where the problems start. Like Sefita said, if Tonga has a 5 year development plan then they have the advantage of inviting donors to the talk table, briefing them that this is our plan and this is what we need, but come on the basis of sharing. But how it is, it's a capacity issue because the recipient country can say this is what we want, and the donor can say no. The donor has the money and the power to say no, and that's why the model needs changing. The recipient country has to change it if they want development to work for their national plan. (Maka, 2013).

Kalafi Moala: The sharing proposition alters the dynamics in the development paradigm. What we have now is the scenario of the helper and the helpless where development is defined by the helper to help himself, basically. But the principle of sharing means equal partnership. It brings in the principle of equality and creates a new paradigm, a new way of thinking, so that the donors and the recipient countries sit at the same table as equal partners. (Moala, 2013b).

Sefita Hao'uli: The New Zealand aid line is pitched as though 'we're responding to the development needs of Pacific Island states.' But it is about putting New Zealand's interests first, New Zealand's economic and political interests, because the thinking is, 'I will get something out of this.' This is when Tonga needs a policy guideline for managing that relationship to meet its 5 year development plan and a 20 year vision for the country. Democracy means having a complete national package, taking stock of the nation, and getting the buy-in from the entire nation that this is our vision for what we want. This is how development will work. If done this way, we understand ourselves better, and there should be a condition that any 5 year plan and 20 year vision seeks to be understood clearly. It should reflect our collective mind-set that this is where we are, here is our total development package, and this is where we will arrive at as a nation. (Hao'uli, 2013b). 


\section{Back to life, back to reality ${ }^{6}$}

The preceding sub-heading, A short play: The parable of sharing, unfolds a discussion excerpt from Sefita Hao'uli, Kalafi Moala, and Melino Maka that took place in the café at AUT University's Manukau campus on the morning of Tuesday November the 12th, 2013. Presented here as an ethnographic transcript, at a glance, it shows the three discussants exchanging ideas by questioning development. What does development mean to donors and recipient countries? Who are the winners and losers in a market driven economy where aid given to poor countries is reciprocated back to wealthy donors by a trade imbalance? (Massey and Taylor, 2004). And how can Tonga, their homeland state, reframe development thinking to manage aid donor relations in respect of making a five year national plan and twenty year vision happen?

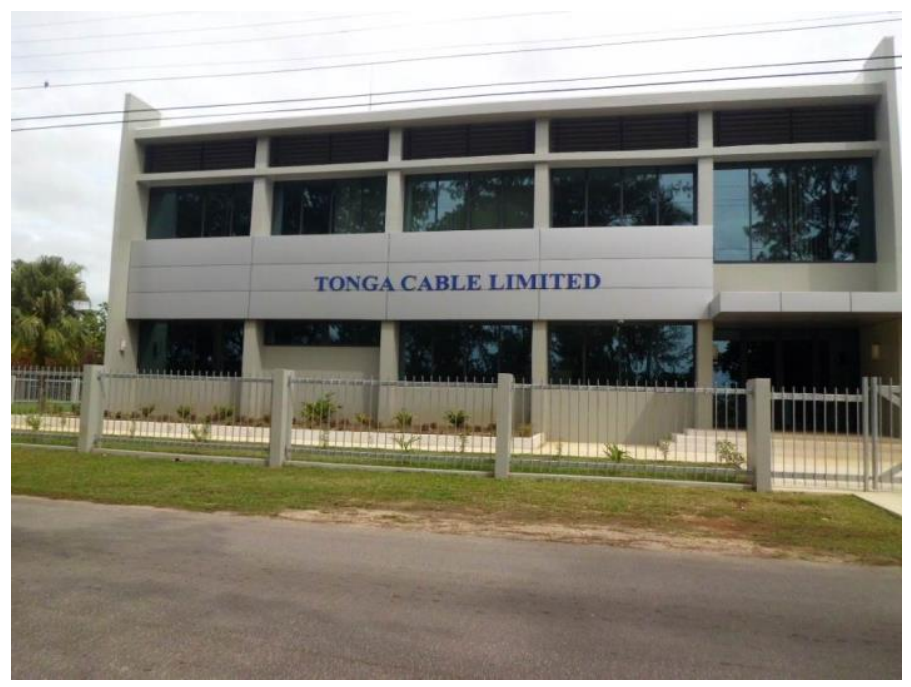

Tonga Cable Limited, a Government of Tonga public enterprise responsible for the national fibre optic cable installed in 2013 bringing broadband internet to the country. 
Collaboratively, their dialogue is idealistic, aspirational, and change-driven, but at the same time mindful of being practical, strategic, and relevant to the majority of Tongan people living in the homeland, not just tailored for a select and privileged few as it has been in the past. In the first essay of four called Rethinking Development in Tonga (Brown Pulu, 2013a), I noted that the straightforward part of the equation is gathering people and ideas, and documenting their dialogues, strategies, and approaches to doing development, alongside analysing the texts, sub-texts, and counter-narratives.

The complex part, by comparison, is actually getting the work done, gaining permission from the top, acquiring consensus from below, and making coordinated change happen not singly at state level, but more significantly on the ground in village communities and everyday lives (Brown Pulu, 2013a, p. 333). Doing development work in a small island developing state like Tonga with a population of 104,941 people becomes, quite simply, a nation building project out of necessity. The population is small, the resources are scarce, and the rifts and factions between social groups and individual leaders are deep and perilous. Therefore, mobilisation for change requires widespread reconciliation and involvement to drive any comprehensive national strategy towards completion.

On the regional stage it was Kalafi Moala who exclaimed in a political commentary, what is our vision statement for selfdetermination? For the independent Polynesian states, do we know what self-determination is without aid donors shaping our reality for us?

Other Pacific nations would do well to go over the points of Commodore Bainimarama's speech, and especially his statement about self-determination of our own destinies as sovereign states. It is precisely this point that many of our Pacific states have fallen weak, in letting aid and funding 
determine what is important to the Pacific rather than determining what needs to be done because it is important to us. (Moala, 2013a).

By no means was Moala advocating for breaking ties with developed countries and going rogue. His inquiry was centred on sovereignty, and how small island developing states might put this into practice. Similar to the cases Epeli Hau'ofa made in his 1990s articles, Our Sea of Islands (1993) and The Ocean in Us (1998), Moala did not see that the smallness of islands and the expansiveness of ocean constricted and isolated a people's capability to maintain sovereignty and selfdetermination over their prospects, humanity, and the will to make independent decisions for their country's affairs and destiny.

Sefita Hao'uli recalled that when Futa Helu was "at his most influential ... in the sixties and seventies," he had distinguished patterns of regular aid in contrast to what he thought was "appropriate aid” (Hao'uli, 2013a).

[An] appropriate technology movement came to the fore in the sixties and seventies when Futa [Helu] was at his most influential. [It is significant to] understanding what his thinking was on the issue of aid and appropriate aid. (Hao'uli, 2013a).

Forty to fifty years ago, an "appropriate technology movement" in Tonga expounded by Futa Helu cautioned that the level of technological development bankrolled by aid donations should, in theory, accurately reflect the human resource, scientific, and industrial capacity of the country. For an archipelago of 176 coral atolls, Tonga in the 1960s and 1970s aid industry held increased expectations of technological advancement. But the condition of Third World countries meant that without sufficient investigation of the long-term viability, usefulness, and environmental 
sustainability of projects and ventures, development models mismatched the places they were developing.

My point is in 2013 the most pressing development challenge facing Tonga is rapid environmental degradation exacerbated by climate change, unpredictable weather patterns, and frequent natural disasters (Television Tonga News, 2013a, 2013b). But are high-tech development projects such as Tonga's fibre optic cable bankrolled by the World Bank, alongside the promise that fast broadband will create internet business, any different to the aid-driven logic that Helu observed in his 20th century era? (Snyder, 2013).

Journalist and political commentator, Pesi Fonua, highlighted a political leadership crisis in Tonga was an urgent concern for the country's direction in economic development.

Tonga's journey of westernization began, about 161 years ago when Tupou I decided that the way forward for Tonga was to accept Christianity, introduce a constitution, with an economy that was based on Tongans owning a piece of land where a man could grow coconuts to make copra, and grow food crops for his family - with the aim of self-sufficiency. But later, when the country was in debt the British took Tonga as a British Protectorate taking charge of its economic and foreign relation affairs. Tonga's British Protectorate status ended in 1973, when Tonga took full control of its international relations and economic affairs. Since 1973 we have been fully responsible for the situation that we find our country in today. Right now we need a leader with a wide vision to think about the future and find different directions - other than just looking for an aid donor or a development partner. (Fonua, 2013).

An established and respected parliamentary reporter for over thirty years, Fonua did not mix his words when pointing out, "Right now we need a leader with a wide vision to think about the future and find different directions - other than just looking for an aid donor or a development partner" (Fonua, 
2013; Johnson, 2013). Skilfully he captured the anxiety at home, as well as the fears of Tongans abroad that because government leadership was at its weakest and most confused and corrupt, the political treachery had intensified the risk that a dictator could rise up at the 2014 election, and if elected to power, suspend the democratic reforms.

\section{Women and youth as a new political force}

Two favourite women writers of mine - Pam Corkery, a Pakeha (white/European) New Zealander radio broadcaster, and Sia Figiel, a Samoan/Polish-American novelist - etched out memorable one-liners on two different topics, democracy and colonisation.

Personal and economic security inevitably takes precedence over democracy because there's nothing in it for so many. (Corkery, 2013).

A fascinating look at how we colonize ourselves which is more lasting, and has deeper undercurrents. Good and necessary work Teena Brown Pulu. Malo 'aupito. (Figiel, 2013).

On closer inspection democracy and colonisation crossed paths in Corkery and Figiel's thoughts, knocking head-first into each other, and ending up being one-and-the-same modern colonialism or economic colonialism - which was the argument Kalafi Moala pitched in his political commentary that began this essay (Moala, 2013a). Their sentiments were hauntingly astute; "economic security takes precedence over democracy" and the way that "we colonize ourselves is more lasting" (Corkery, 2013; Figiel, 2013).

The power of modern colonialism is that democracy, like development, has become an empty reference that means anything to everyone and nothing in particular. And if "there's nothing in it for so many," then understandably the way that 
"we colonize ourselves is more lasting" (Corkery, 2013, Figiel, 2013).

In Tonga's historical case, internal colonisation offers financially vulnerable people, the poor commoners at risk of losing what little they have in an unstable economy and political environment, a false but none-the-less comforting sense of familiarity, stability, and permanence. Saturated by a fast-changing world that ordinary people have little say in, and control over, the local colonial state does not dissipate but is revalidated as Tongan nationalism (Jolly, 2008; Rogers, 2013).

Which brings me to "next year's election in Tonga" 2014, an obvious site of political contestation and social anxiety that Sefita Hao'uli raised (Hao'uli, 2013c).

Next year's election in Tonga will mean that 27 year old voters were born when 'Akilisi Pohiva first entered parliament in 1987. The population statistics may support my contention that the majority of voters next year would have been brought up during the [pro-democracy] progressive political agenda. The question should be asked: What have been the gains over these years for 30 year old Tongans? I'm raising the issue so that in reviewing, we should be able to get a fix on what needs to be done to reframe the next 30 years. [There] is the neglect of women's political ambitions and aspirations. And we're talking about $50 \%$ of the population. Not too far behind is the neglect of our youth. In both cases, we're also talking about social issues. These have been put aside as either being too marginal to the political reform or just too difficult or both. There was no specific focus on them at all. These are two new challenges for anyone who wants to pick up on what appears to be a flagging pro-democratic movement. Again it comes down to a lack of a cohesive political party doctrine or agenda that could be sold as a credible and practical package and defended in total. What we've seen has been a piecemeal approach to reforms. Whoever can mobilise the women's and youth factions and to appreciate that the best organised political party in the country 
is the 'Noble's Party' will become the new political force. I'm hoping that the new movement will be led by a woman. (Hao'uli, 2013c).

No one disagreed with Sefita's logic, not Kalafi, Melino, or me. His polished analysis of "a flagging pro-democratic movement" bereft of established canons; the reality that the Tongan nobility are the "organised" class group to function pragmatically like a political party; and the question mark around women and youth as cohorts of voters and parliamentary candidates; was fundamental to understanding where Tonga was located and dislocated a year out from the election (Hao'uli, 2013c).

The one gripe I had was if women were to head a "new movement" in party politics, then I would not want to see a member of the royal family, a noble's mother, a noble's wife, a noble's mistress, a noble's sister, or a noble's daughter, barge their way in front of women more deserving with greater skill and work merit, to take over the helm (Hao'uli, 2013c). "That would hardly be a win for women in politics," was the response I sent back to the three discussants, letting these Tongan men feel my disapproval (Brown Pulu, 2013b).

As discriminatory as it might seem, the upper-class committed to upholding a traditional hierarchy and its power and asset base as land-owners, the landlords collecting rent on estate leases, were aptly represented by nine nobles' representatives to parliament. I did not believe the country was obliged to load excess baggage alongside the heavy weights who possessed adequate numbers to maintain a balance of power in a crowded, chaotic, complicated House. Women of the upper class had enough power and privilege, and were in no honest or experiential position to speak for ordinary women, the majority with whom they shared as little as possible while taking as much from their favourable position in society as they could. 
To close this second essay of four, Kalafi Moala's sentiments that lest we forget the past is timely for the month of November. It is a bittersweet reminder of the roots and routes of Tonga's pro-democracy movement, particularly November the 16th of 2013, that fateful Black Friday as locals recall it, when Nuku'alofa was rioted, looted, and burned. In his second book, Moala quoted Friedrich Nietzsche who wrote, "Whoever fights monsters should see to it that in the process he does not become a monster" (Moala, 2009, p. 39). Nothing could be truer in remembering Nuku'alofa on November 16th, the day the old town burnt to the ground. To achieve what purpose is still unclear and marked by debris, dirt, and the deaths of eight people.

It is my hope that the younger generation of Tongan leaders, thinkers, writers, critics, artists, poets, and performers, will excavate this incident, episode, aftermath, and speak truth to a time in history that eludes, confounds, and conflicts us. Distinctive from my generation who are middleaged, and Kalafi, Sefita, and Melino's age group who are senior in our communities at home and abroad, I feel that despite the current setbacks in moving Tonga forward, they will obtain greater social freedom than Tongans before them and by having secured this for their own, be less restrained to ask hard questions and pursue complex answers that we could not.

Every generation has a social responsibility to improve on the last. They must. Without it, they risk sacrificing the next generation's inheritance to wilful ignorance, unrepentant arrogance, and past lessons about our actions, the agonising aspects of our history, unlearned.

16/11 was truly one of the saddest days of my life. I grieved for the fact that here was a movement I had given years of my life to promote, and yet they had done the unimaginable. In one stroke of stupidity, the movement had made itself odious to those who have any sense of morality, a violator of the laws 
of the land, and essentially irrelevant to any further negotiation and planning for the future political development of Tonga. It lost its reason for being, because it ceased to be a tool for serving the people, the movement had become a weapon of havoc. It became a tool that uses people rather than working with people. (Moala, 2009, p. 39).

\section{A short play: Scene two: Postscript on the hymn}

Sefita Hao'uli: On speed-reading this, can I suggest that the hymn we're referring to be offered in full with a translation and perhaps its origins ought to be brought into context as well. It may change the emphasis that Teena has given to the "Indian" reference as I think that the references to our Pacific neighbours are even more offensive, certainly by today's standards. For your information Teena, the song can be seen as a song of praise - for Tonga's willingness to embrace God and Christianity, but it then went on to compare that willingness with the reluctance and difficulties experienced by missionaries in establishing their missions abroad.

You'll have to remember also that Tonga, through its welleducated Christian scholars and willingness to serve, were already involved in sending missionaries "abroad" to Melanesia and Micronesia in particular. Those who went abroad were often seen to be saintly and paying the supreme sacrifice in the name of God. Accounts of their difficult lives abroad were reported frequently in the Tohi Fanongonongo of the Wesleyan church.

The Hau'ofa's were among them and as you quote their offspring Epeli frequently, there's a great deal of rationalisation to be done to put in context the Tongan jingoism of old, the failure to make amends now that the world has changed - and that it is in fact more likely to be "poor Tonga" rather than "poor everyone else." This is likely to provoke a strong reaction from our community so it's best to make sure that the comments are well-founded and defensible. I stand corrected on the origins, 
but as it is a Wesleyan hymn only, it could have been the work of Moulton and his scholars? (Hao'uli, 2013d).

Teena Brown Pulu: Thank you Sef for saving my ass. Grateful to put a translation and explanation in the essay. It can go in an Appendix with explanatory notes, and as well, I can reword some of the section, 'National pride and prejudice.' Melino, trust you to keep quiet about this because you would've sung the hymn at Toloa.

Everything you've said here makes sense to me, Sef. I don't want to counter-offend the loyalists and traditionalists but for goodness sake, the hymn is a tad outdated and the new missionaries of today that Kalafi mentors don't sing songs like that. I'll get told off by a lot of people for disrespecting the Wesleyan church history which is integrated into national identity, but that's okay. I'll survive to write articles 3 and 4. Epeli's family were missionaries in Papua New Guinea, weren't they? Oh wow, and he was so radical in his thinking. (Brown Pulu, 2013c).

Melino Maka: My parents spent 5 years in the Solomon [Islands] and two of my brothers were born there. The hymn was written during that time using some Tongan metaphors [that] are very powerful and can be translated so many [different] ways. We learnt and memorised the words, but later started to look into the meaning of these very powerful words. One of the Wesleyan church hymns to raise funds for the missionaries' work abroad, hymn number 423, the first verse goes like this:

Fanongo ki he Tangi 'a si'i Initia mo Siaina tokolahi kae fonu mala'ia. Fanongo e fanongo, he kole 'oku fai ki Tonga monu'ia "kainga 'ofa mai!"

Translation: Listen to the cry from poor India and overcrowded China, full of sin, listen please listen to this appeal. To privileged Tonga, please help us!

The last verse is very interesting: 
Tau 'oho 'o hamusi, tau li ha maea e: Foaki 'etau pa'anga, mo toutou lotu pe. Na'a hoko mail he 'aho, he 'aho he 'Otua' 'o 'eke 'e he 'Eiki. 'Koma'aa ho tokoua?

Translation: We leap to salvation. We throw in the rope: We donate our money, and always pray. If the day comes, the day with God, the Lord asks, where is your brother? (Maka, 2013b).

Teena Brown Pulu: Melino, thank you so much for sharing your knowledge, here. I'll add a postscript at the end of the essay with your translation and explanation of excerpts from the hymn. I'll also weave in Sefita's discussion on historical context, and why the hymn had power and persuasion at the time when you were growing up in Tonga.

Solomon Islands missionaries, your parents? I remember you saying you were born in Vava'u when your father was a clergyman, and then moved to Tatakamotonga as a child to live with your Grandma and attend Toloa. My goodness Melino; you've had the life of a missionary's son like Epeli Hau'ofa. I'm impressed that both you and Epeli are open-minded and openhearted to people of all races and cultures, and have spent most of your adult lives mixing and working in the wider world outside of Tonga and traditional church culture, considering you grew up in church families. (Brown Pulu, 2013c). 


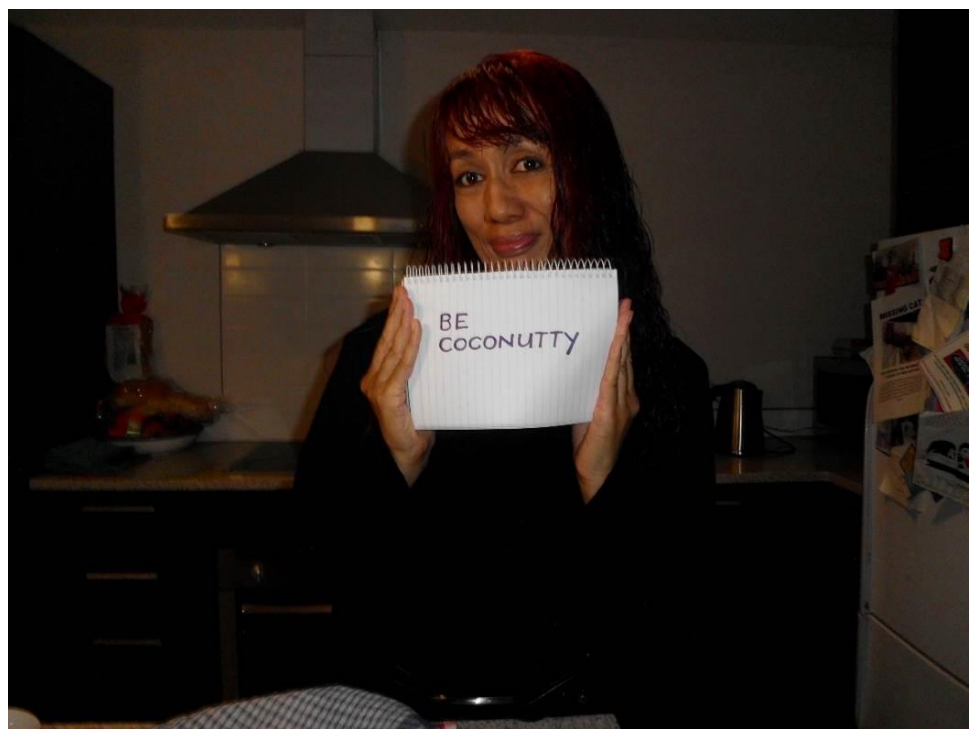

The author, Teena Brown Pulu, with a sign for 'Be Week' organised by the South Auckland Poets Collective in October 2013. Poets and supporters of the collective were invited to write personal mottos using ' $B e$ ' as the determiner. 'Be Coconutty' was intended to mean be an unconventional character.

\section{A poem: Rewording national pride and prejudice}

I do not know how to reword

National pride and prejudice

Many stories I have learned

Collected, stored in memory

I would like to delete from files

This is not my history

But someone else's

And because they are Tongan

I am trapped here by name association

I am $T$ for Teena

$T$ for part Tongan 
Like my English ancestor's tea imported from India

English tea in thirty degree Tongan heat

That makes you sweat salt water tears

In an ocean of mixed-blood, mixed up, emotion

I am not $D$ for Donga like a real Dongan

That dalks broper Dongan with a $D$ for $T$ and a $B$ for $P$

I think that will always be my exit

From suffocating coloured roots

But the white part of me, my routes, is the mother of colonialism

\section{Teena Brown Pulu}




\section{References}

Anderson, D. and Ackerman Anderson, L. (2010). Beyond Change Management: How to Achieve Breakthrough Results Through Conscious Change Leadership. San Francisco, California, USA: Pfeiffer.

Austen, J. (1813). Pride and Prejudice. London, United Kingdom: T. Egerton, Whitehall.

Austen, J. (1811). Sense and Sensibility. London, United Kingdom: T. Egerton, Whitehall.

Bertram, G. (2006). Introduction: The MIRAB model in the twenty-first century. Asia Pacific Viewpoint, 47 (1): 1-13.

Brown Pulu, T. (2013a). Rethinking Development in Tonga: Dialogues with Sefita Hao'uli, Kalafi Moala, and Melino Maka. Te Kaharoa: The e-Journal on Indigenous Pacific Issues, 6 (1): 306-344.

Brown Pulu, T. (2013b). Email correspondence to Sefita Hao'uli, Kalafi Moala, and Melino Maka. Auckland, New Zealand, November 14.

Brown Pulu, T. (2013c). Email correspondence to Sefita Hao'uli, Kalafi Moala, and Melino Maka. Auckland, New Zealand, November 18.

Corkery, P. (2013). Get a grip, Len, you've been such a let-down. The New Zealand Herald, Auckland, New Zealand, October 11. Retrieved from

http:/ / www.nzherald.co.nz/nz/news/article.cfm?c_id=1\&objectid=111 38262

Craymer, L. (2012). China macht sich den Sudpazifik gefugig. The Wall Street Journal: International, New York, USA, April 27. Retrieved from

http:/ / www.wsj.de/article/SB1000142405270230481130457736927 1394024652.html

Derrida, J. (1999). Forgiving the Unforgivable: Public Lecture. Auckland Town Hall, Auckland, New Zealand, August 18.

Figiel, S. (2013). Facebook Comment to Teena Brown Pulu. Tampa, Florida, USA, November 15.

Fonua, P. (2013). Tonga needs visionary leadership to develop its economy: Editor's Comment. Matangi Tonga Online, Nuku'alofa, Tonga, October 14. Retrieved from

http://matangitonga.to/2013/10/14/tonga-needs-visionaryleadership-develop-its-economy

Foucault, M. (1983). Parrhesia and the crisis of democratic institutions. Audio Archive: Lecture by Michel Foucault, University of California at Berkeley Campus, California, United States, October 31.

Foucault, M. (1972). The Archaeology of Knowledge and the Discourse on Language, Translated by A. M. Sheridan Smith. New York, USA: Pantheon Books. 
Foucault, M. (1970). The Order of Discourse. Inaugural Lecture at the College de France, Paris, France, December 2. Reprinted in Untying the Text: A Post-Structuralist Reader, edited by R. Young. London, United Kingdom: Routledge and Kegan Paul, Pp. 48-78.

Freire, P. (1970). Pedagogy of the Oppressed. New York, USA: Herder and Herder.

Gates, H. L. (1988). The Signifying Monkey: A Theory of African American Literary Criticism. New York, USA: Oxford University Press.

Gramsci, A. (1971). Selections from the Prison Notebooks of Antonio Gramsci. New York, USA: International Publishers.

Hammond, D. (2005). The Signifying Monkey. An excerpt from the film, Doug Hammond, The Talking Drum, produced by Helmut Schonleitner, An AKKUart production, Austria, May 25. Retrieved from

https://www.youtube.com/watch?v=hJAusfEalfo

Hao'uli, S. (2013a). Email correspondence to Teena Brown Pulu, Kalafi Moala and Melino Maka. Auckland, New Zealand, September 28.

Hao'uli, S. (2013b). Discussion 2: Sefita Hao'uli, Kalafi Moala, and Melino Maka. Auckland, New Zealand, November 12.

Hao'uli, S. (2013c). Email correspondence to Teena Brown Pulu, Kalafi Moala, and Melino Maka. Auckland, New Zealand, November 14.

Hao'uli, S. (2013d). Email correspondence to Teena Brown Pulu, Kalafi Moala, and Melino Maka. Auckland, New Zealand, November 18.

Hau'ofa, E. (1993). Our Sea of Islands. In A New Oceania: Rediscovering Our Sea of Islands, edited by E. Waddell, V. Naidu, and E. Hau'ofa. Suva, Fiji: University of the South Pacific, School of Social and Economic Development.

Hau'ofa, E. (1998). The Ocean in Us. The Contemporary Pacific, 10 (2): 391-410.

Hau'ofa, E. (2000). The Ocean in Us. In Culture and Sustainable Development, edited by A. Hooper. Canberra, Australia: ANU E Press, Pp. 32-43.

Hau'ofa, E. (2008). Our Sea of Islands. In We Are The Ocean: Selected Works by Epeli Hau'ofa, Foreword by Geoffrey White. Honolulu, USA: University of Hawai'i Press, Pp. 27-40.

Hobsbawm, E. (1983). Introduction: Inventing Traditions. In The Invention of Tradition, edited by $\mathrm{E}$. Hobsbawm and T. Ranger. Cambridge, United Kingdom: Cambridge University Press, Pp. 114.

Hobsbawm, E. and Ranger, T. (Eds.) (1983). The Invention of Tradition. Cambridge, United Kingdom: Cambridge University Press. 
Johnson, G. (2013). Ad hoc decisions don't make it in an increasingly complex world. Pacific Politics: Political news and analysis bought to you by the Pacific Institute of Public Policy, Port Vila, Vanuatu, October 9. Retrieved from

http://pacificpolitics.com/2013/10/ad-hoc-decisions-dont-make-itin-an-increasingly-complex-world/

Jolly, M. (2008). The South in Southern Theory: Antipodean Reflections on the Pacific. Australian Humanities Review, 44 (March). Retrieved from

http://www.australianhumanitiesreview.org/archive/Issue-March2008/jolly.html

Kochman, T. (Ed.) (1972). Rappin' and Stylin' Out: Communication in Urban Black America. Urbana Champaigne, United States: University of Illinois Press.

Latukefu, S. (1974). Church and State in Tonga: The Wesleyan Methodist Missionaries and Political Development, 1822-1875. Canberra, Australia: Australian National University Press.

Leone, S. (1966). The Good, the Bad and the Ugly. Beverly Hills, California, United States: United Artists, An MGM Company.

Maka, M. (2013a). Discussion 2: Sefita Hao'uli, Kalafi Moala, and Melino Maka. Auckland, New Zealand, November 12.

Maka, M. (2013b). Email correspondence to Teena Brown Pulu, Sefita Hao'uli, and Kalafi Moala. Auckland, New Zealand, November 18.

Massey, D. and Taylor, J. (Eds.) (2004). International Migration: Prospects and Policies in a Global Market. Oxford, United Kingdom: Oxford University Press.

Moala, K. (2013a). Self-determination thinking crucial for Post-2015. Pacific Politics: Political news and analysis brought to you by the Pacific Institute of Public Policy, Port Vila, Vanuatu, October 4. Retrieved from

http:/ / pacificpolitics.com/2013/10/self-determination-thinkingcrucial-for-post-2015/

Moala, K. (2013b). Discussion 2: Sefita Hao'uli, Kalafi Moala, and Melino Maka. Auckland, New Zealand, November 12.

Moala, K. (2009). Tonga: In Search of the Friendly Islands. Honolulu and Auckland: Pasifika Foundation and the Pacific Media Centre.

Rogers, J. (2013). Small Islands, Big Challenges, Maximising Opportunities for Development: A Pacific Perspective. The Future of International Development in Asia and the Pacific Conference, Australian National University, Canberra, Australia, May 10. Retrieved from

http://www.youtube.com/watch?v=otVsX0ZCvgY 
Said, E. (1978). Orientalism. London, United Kingdom: Routledge and Kegan Paul.

Snyder, M. (2013). World Bank Whistle Blower Reveals How The Global Elite Rule The World. Global Research: Centre for Research on Globalization, Montreal, Canada, October 6. Retrieved from

http://www.globalresearch.ca/world-bank-whistleblower-reveals-howthe-global-elite-rule-the-world/5353130

Spivak, G. C. (1990). The Post-Colonial Critic: Interviews, Strategies, Dialogues. New York, USA: Routledge.

Television Tonga News. (2013a). Sione Taumoefolau and Rosamond Bing cited in Television Tonga News in English. Tonga Broadcasting Commission, Nuku'alofa, Tonga, October 11 . Retrieved from

https: / / www.youtube.com/watch?v=7GhbyQOzJSk\&feature=c4overview\&list=UUJsR-wS1oz5i-0hNUsWU_9w

Television Tonga News. (2013b). Walter Holakeituai cited in Television Tonga News in English. Tonga Broadcasting Commission, Nuku'alofa, Tonga, November 11. Retrieved from

https: / / www.youtube.com $/$ watch?v=qX5ncdX6NrM\&list=UUJsRwS1oz5i-OhNUsWU_9w

Young, R. (1990). White Mythologies: Writing History and the West. London, United Kingdom: Routledge.

Young, R. (Ed.) (1981). Untying the Text: A Post-Structuralist Reader. London, United Kingdom: Routledge and Kegan Paul.

\section{Tongan glossary}

Kai suka A literal translation is to eat sugar.

\section{Photographs}

Nuku'alofa, Tonga, Photograph by Lucy Craymer, The Wall Street Journal, New York, USA, 27 April 2012.

Melino Maka, Sefita Hao'uli, Kalafi Moala, Photograph by Teena Brown Pulu, AUT University Manukau Campus, Auckland, New Zealand, 13 November 2013.

Epeli Hau'ofa, Photograph by Ann Tarte, Oceania Centre for Arts and Culture, University of the South Pacific, Suva, Fiji, March 2008.

Handcraft, Photograph by Teena Brown Pulu, Auckland, New Zealand, 17 November 2013. 
Wesleyan Church, Photograph by Melino Maka, Nukunuku, Tonga, 12 June 2011.

Wesleyan Church, Photograph by Melino Maka, Nukunuku, Tonga, 12 June 2011.

Chinese workers, Photograph by Melino Maka, Nuku'alofa, Tonga, 7 June 2011.

Tonga Cable Limited, Photograph by Teena Brown Pulu, Sopu, Tonga, September 2013.

Teena Brown Pulu, Photograph by Ani-Kaa Amoamo, Auckland, New Zealand, October 2013.

\section{Endnotes}

See Gates, H. L. (1988). The Signifying Monkey: A Theory of African American Literary Criticism. New York, United States: Oxford University Press.

The image of black tradition has suffered from the lack of sophisticated scholarly attention to it. I would hope that decades of careful collection and establishment of texts will be followed by decades of close readings, interpretation, and speculation. This book can be seen as a scholarly return to the relationship between black vernacular and formal traditions, ... (Gates, 1988, p. xii).

Gates' book links "black vernacular" to scholarly "traditions" of literary and cultural analysis (Gates, 1998). This is an academic style and strategy I hope to see younger generation Tongan researchers undertake in connecting the "organic intellectualism" (Gramsci, 1971) of grassroots thinkers, artists, and activists, to the "formal traditions" (Gates, 1998) of scholarly writing.

2 See Austen, J. (1813). Pride and Prejudice. London, United Kingdom: T. Egerton, Whitehall.

The reference to pride and prejudice is a wordplay on Jane Austen's 19th century romantic novel, Pride and Prejudice, first published in 1813.

3 See Austen, J. (1811). Sense and Sensibility. London, United Kingdom: T. Egerton, Whitehall.

The reference to sense and sensibility is a wordplay on Jane Austen's 19 th century romantic novel, Sense and Sensibility, first published in 1811. 
4 See Leone, S. (1966). The Good, the Bad and the Ugly. Beverly Hills, California, United States: United Films, An MGM Company.

The reference to The Good, the Bad and the Ugly is a wordplay on the name of the Italian spaghetti Western directed by Sergio Leone in 1966 and starring Clint Eastwood, Lee Van Cleef, and Eli Wallach.

$5 \quad$ See Link to Real Tonga website: $h$ ttp://www.realtonga.to/

The reference to Real Tonga is a wordplay on the name of the aviation company in the Kingdom of Tonga contracted by the Tongan state in 2013 to provide a domestic flight service to the outer islands from the main island of Tongatapu.

6 See Soul II Soul. (1989). Back to Life. CD Single (3:52 minutes), London, United Kingdom, Virgin Records.

The reference to Back to life, back to reality is a wordplay on a CD single produced by a 1980s/1990s British rhythm and blues dance group called Soul II Soul. The single was called Back to life and was released in 1989. 